\title{
PENGARUH CITRA MEREK DAN HARGA TERHADAP KEPUTUSAN PEMBELIAN SEPEDA MOTOR HONDA BEAT (Studi Kasus Mahasiswa Fakultas Ekonomi dan Bisnis Universitas Bandar Lampung)
}

\author{
Toton ${ }^{1}$, Bunga Vidya Putri \\ Fakultas Ekonomi dan Bisnis Universitas Bandar Lampung \\ Jl. ZA Pagar Alam No. 26, Labuhan Ratu, Bandar Lampung. \\ Email : toton@ubl.ac.id; Bunga.15011042@student.ubl.ac.id
}

\begin{abstract}
Problems in this research was motorcycle sales brand honda beat to PT .Astra Honda Motor experienced fluctuations, sales the highest was in april of 7,03\%, while declining sales the highest was in june of 5,63\%. The problems formulated is whether brand image and prices influential of the decision the purchase motorcycle honda beat in students of the Faculty Business And Economy University Bandar Lampung.Population in this research is students of the faculty business and economy university bandar lampung were 96 respondents, data collection use spss 23.0 version. Based on the results of discussion a conclusion can be drawn that obtained the regression equation is linear multiple of $y=8,018+1,084 x 1+0,459 \times 2$, value $f$ statistic of 58,608 with significance of 0.000 . Value the coefficients determination 75,4\%.
\end{abstract}

Keywords : Brand Image, Price, and Purchase Decision

\begin{abstract}
ABSTRAK
Masalah dalam penelitian ini adalah penjualan sepeda motor merek Honda Beat pada PT. Astra Honda Motor mengalami fluktuasi, Penjualan tertinggi terjadi pada bulan April sebesar 7,03\%, Sedangkan penurunan penjualan tertinggi terjadi pada bulan Juni sebesar 5,63\%. Permasalahan yang dirumuskan adalah apakah Citra Merek dan Harga berpengaruh terhadap keputusan Pembelian Sepeda Motor Honda Beat pada Mahasiswa Fakultas Ekonomi dan Bisnis Universitas Bandar Lampung. Populasi dalam penelitian ini adalah mahasiswa fakultas ekonomi dan bisnis universitas Bandar lampung berjumlah 96 orang responden, pengumpulan data menggunakan SPSS versi 23.0 . Berdasarkan hasil pembahasan dapat ditarik kesimpulan bahwa diperoleh persamaan regresi linier berganda sebesar $\mathrm{Y}=8,018+1,084 \mathrm{X} 1+0,459 \mathrm{X} 2$, nilai $\mathrm{F}$ statistic sebesar 58,608 dengan signifikansi sebesar 0.000. Nilai koefisien determinasi $\left(\mathrm{R}^{2}\right)$ diperoleh sebesar 0,568. Dengan demikian, Secara bersama-sama, Citra Merek dan Harga berpengaruh positif cukup tinggi terhadap Keputusan Pembelian yaitu sebesar 75,4\%.
\end{abstract}

Kata Kunci : Citra Merek, Harga, dan Keputusan Pembelian. 


\section{PENDAHULUAN}

Seiring dengan perkembangan jaman dan semakin meningkatnya kebutuhan alat transportasi membawa angin segar bagi perusahaan otomotif terutama di bidang sepeda motor, yang sangat dibutuhkan oleh banyak konsumen, selain harganya yang terjangkau dan mudah perawatannya, memacu para pengusaha sepeda motor untuk memaksimalkan dalam mempertahankan atau meningkatkan produktifitas perusahaan agar dapat bersaing dengan perusahaan sejenis lainnya.

Terdapat beberapa merek sepeda motor yang tersebar di seluruh Indonesia antara lain Honda, Yamaha, Suzuki, TVS, Kawasaki, dan lain sebagainya. Berdasarkan data Asosiasi Industri Motor Indonesia (AISI) tahun 2017 menyatakan bahwa terdapat tiga merek sepeda motor yang bersaing ketat untuk mendapatkan pangsa pasar di Indonesia yaitu sepeda motor merek Honda berada diposisi pertama sebagai pemimpin pasar sepeda motor di Indonesia, selanjutnya diposisi kedua terdapat sepeda motor merek Yamaha, dan diposisi ketiga terdapat sepeda motor merek Suzuki.

Honda adalah merek sepeda motor asal jepang yang didirikan pada 24 september 1948 oleh Soichiro Honda. Honda merupakan produsen sepeda motor terbesar di dunia sejak 1959. Honda pun mengembangkan area bisnis salah satunya di Indonesia yang dinaungi oleh perusahaan Astra Internasional.

Honda merupakan merek yang sangat banyak diminati oleh sebagian besar masyarakat Indonesia, terbukti bahwa pemasar motor Honda telah berhasil membangun reputasi yang berimbas pada loyalitas konsumen. Keberhasilan suatu merek ditunjukkan dengan penjualan produk lewat pembelian.konsumen, saat ini sangat kritis dalam memilih suatu produk, sampai pada pengambilan keputusan untuk membeli produk tersebut. Honda Beat yang selalu menjadi unggulan mampu menduduki posisi di Top Brand Award dan selalu mengalami peningkatan penjualan.

Tabel 1.1

Top Brand Index Sepeda Motor Matic Tahun 2017

\begin{tabular}{|c|c|c|}
\hline Merek & TBI & TOP \\
\hline Yamaha Mio & $32,1 \%$ & TOP \\
\hline Honda Beat & $29,9 \%$ & TOP \\
\hline Honda Vario & $21,8 \%$ & TOP \\
\hline Honda Scoopy & $4,3 \%$ & - \\
\hline
\end{tabular}

Sumber :www.topbrand-award.com

Berdasarkan tabel 1.1, terlihat bahwa Top Brand Sepeda Motor Matic pada tahun 2017 di posisi pertama diduduki oleh Motor Matic dari perusahaan Yamaha dengan merek Yamaha Mio dengan presetase sebesar 32,1\% dan mendapat gelar Top Brand, diposisi kedua terdapat sepeda motor merek Honda Beat dengan persentase sebesar 29,9\% dan mendapat gelar Top Brand, diposisi ketiga ditempati oleh Honda Vario dengan persentase sebesar 21,8\% dan mendapat gelar Top Brand, dan diposisi terakhir di duduki oleh Honda Scoopy dengan presentase sebesar 4,3\%.

Ada beberapa faktor yang mempengaruhi seseorang untuk melakukan keputusan pembelian suatu produk, antara lain ialah citra merek (brand image) dan harga (price) Dimana, Citra Merek (Brand Image) adalah presepsi dan keyakinan yang dipegang oleh konsumen, seperti yang tercerminkan asosiasi yang tertanam dalam ingatan pelanggan, yang selalu diingat pertama kali saat mendengar slogan tertanam dibenak konsumennya.

Harga adalah sesuatu yang dibutuhkan untuk mendapatkan suatu kombinasi antara pelayanan ditambah produk dengan membayar jumlah uang yang sudah menjadi patokan. Sangat penting dalam mempengaruhi keputusan konsumen dalam membeli produk, sehingga sangat 
menentukan keberhasilan pemasaran suatu produk.

Tabel 1.2

Daftar Harga Sepeda Motor Honda Beat Bulan September Tahun 2018

\begin{tabular}{|c|c|c|}
\hline No & Tipe & Harga (Rp) \\
\hline 1 & Beat Sporty CW & 15.450 .000 \\
\hline 2 & Beat Sporty CBS & 15.650 .000 \\
\hline 3 & Beat Sporty CBS ISS & 16.150 .000 \\
\hline 4 & Beat Pop CW & 15.000 .000 \\
\hline 5 & Beat Pop CBS & 15.200 .000 \\
\hline 6 & Beat Pop CBS - ISS & 15.700 .000 \\
\hline 7 & Beat Street & 16.125 .000 \\
\hline
\end{tabular}

Sumber :www.astra-honda.com/price-list\#matic

Berdasarkan tabel 1.2 diatas, terlihat bahwa harga sepeda motor Honda Beat tertinggi dipasaran adalah Honda Beat Tipe Beat Sporty CBS ISS dengan harga Rp16.150.000 dan tipe Beat Street dengan harga Rp16.125.000. Sedangkan harga Honda Beat terendah adalah tipe Beat Pop CW dengan harga Rp15.000.000.

Berdasarkan tabel 1.3 diatas, terlihat bahwa harga sepeda motor Yamaha Mio yang tertinggi adalah tipe Yamaha Mio M3 125 AKS SSS dengan harga Rp16.100.000. Sedangkan harga sepeda motor Yamaha Mio yang terendah adalah tipe Yamaha Mio M3 125 dan Yamaha Mio $\mathrm{Z}$ dengan harga Rp15.200.000.

Tabel 1.3

Daftar Harga Sepeda Motor Yamaha Mio Bulan September Tahun 2018

\begin{tabular}{|c|c|c|}
\hline No & Tipe & Harga (Rp) \\
\hline 1 & Yamaha Mio S & 15.750 .000 \\
\hline 2 & Yamaha Mio M3 125 AKS SSS & 16.100 .000 \\
\hline 3 & Yamaha Mio M3 125 & 15.200 .000 \\
\hline 4 & Yamaha Mio Z & 15.200 .000 \\
\hline
\end{tabular}

Sumber :www.otomotifo.com/harga-yamaha-mio-2018/

Keputusan pembelian adalah keputusan konsumen mengenai preferensi atas merek-merek yang ada didalam kumpulan pilihan. Keputusan konsumen untuk memodifikasi, menunda atau menghindari keputusan pembelian sangat dipengaruhi oleh resiko yang terpikirkan. Besarnya resiko yang dipikirkan berbedabeda menurut besarnya uang yang dipertaruhkan, besarnya ketidak pastian atribut, dan besarnya kepercayaan diri konsumen. Para konsumen mengembangkan rutinitas tertentu untuk mengurangi resiko, seperti penghindaran keputusan pengambilan informasi dari teman-teman, dan preferensi atas nama merek dalam negeri serta garansi.

Tabel 1.4

Data Penjualan Sepeda Motor Merek Honda Beat PadaPT.Astra Honda Motor Sukarame Tahun 2017

\begin{tabular}{|c|c|c|c|c|}
\hline Bulan & $\begin{array}{c}\text { Target } \\
\text { (Unit) }\end{array}$ & $\begin{array}{c}\text { Penjualan } \\
\text { (Unit) }\end{array}$ & $\begin{array}{c}\text { Perkembangan } \\
\text { Penjualan } \\
\text { (Unit) }\end{array}$ & $\begin{array}{c}\text { Perkembangan } \\
\text { Penjualan } \\
(\%)\end{array}$ \\
\hline Januari & 125 & 127 & - & - \\
\hline Februari & 125 & 132 & 5 & 3.93 \\
\hline Maret & 125 & 128 & $(4)$ & $(3.03)$ \\
\hline April & 125 & 120 & $(8)$ & $(6.25)$ \\
\hline Mei & 125 & 129 & 9 & 7.5 \\
\hline Juni & 125 & 125 & $(4)$ & $(3.1)$ \\
\hline Juli & 125 & 122 & $(3)$ & $(2.4)$ \\
\hline Agustus & 125 & 130 & 8 & 6.5 \\
\hline September & 125 & 128 & $(2)$ & $(1.5)$ \\
\hline Oktober & 125 & 125 & $(3)$ & $(2,3)$ \\
\hline November & 125 & 122 & $(3)$ & $(2.4)$ \\
\hline Desember & 125 & 130 & 8 & 6.5 \\
\hline Jumlah & $\mathbf{1 5 0 0}$ & $\mathbf{1 5 1 8}$ & $\mathbf{3})$ & $\mathbf{0 . 2 8}$ \\
\hline Rata-Rata & $\mathbf{1 2 5}$ & $\mathbf{1 2 6}$ & - & \\
\hline Sumber:PT. AstraHondaMotorSukarame & & \\
\hline
\end{tabular}

Berdasarkan Tabel 1.4 dapat dilihat bahwa penjualan sepeda motor merek Honda Beat pada PT. Astra Honda Motor mengalami fluktuasi cendrung menurun. Penurunan tertinggi terjadi pada bulan April sebesar $6.25 \%$.

Berdasarkan uraian pada halaman sebelumnya, penulis mengambil judul penelitian "Pengaruh Citra Merek dan Harga Terhadap Keputusan Pembelian 
Sepeda Motor Honda Beat (Studi Kasus Mahasiswa Fakultas Ekonomi dan Bisnis Universitas Bandar Lampung)".

Berdasarkan tabel penjabaran latar belakang

diatas dapat diketahui masalah penelitian yaitu :"Berdasarkan tabel 1.4 data penjualan sepeda motor Honda beat pada tahun 2017 terlihat bahwa keputusan pembelian sepeda motor Honda beat pada PT. Astra Honda Motor Sukarame mengalami fluktuasi cendrung menurun sebesar-3,03\% pada bulan maret, 6,25\% pada bulan april, 3,1\% pada bulan juni, 2,4\% pada bulan juli, 1,5\% pada bulan September, 2,3\% pada bu;an oktober dan 2,4\% pada bulan November. Namun rata-rata perkembangan yang cendrung turun sebesar 0,28\%." Dan Berdasarkan masalah yang diuraikan diatas, pokok masalah yang dikaji dalam penelitian ini dapat dirumuskan sebagai berikut : "Apakah Keputusan Pembelian Sepeda Motor Honda Beat pada Mahasiswa FEB Universitas Bandar Lampung dipengaruhi oleh citra merek dan harga?"

\section{KERANGKA PEMIKIRAN}

Citra merek (Brand Image) merupakan representasi dsri keselurusan persepsi terhadap merek dan dibentuk dari informasi dan pengalam masalalu terhadap merek itu. Menurut setiadi (2003:180).

Menurut Keller (2013:247), terdapat tiga Indikator Citra Merek, yaitu :

1. Favorability of brand association

2. Strength of brand association

3. Uniqueness of brand association

Definisi harga menurut Kotler dan Armstrong (2001: 439) adalah sejumlah uang yang dibebankan atas suatu produk atau jasa, atau jumlah dari nilai yang ditukar konsumen atas manfaat-manfaat karena memiliki atau menggunakan produk atau jasa tersebut.
Di bawah ini penjelasan empat ukuran harga, yaitu:

1. Keterjangkauan harga

2. Daya Saing harga.

3. Kesesuaian harga dengan kualitas produk

4. Kesesuaian harga dengan manfaat

Menurut Schiffman dan Kanuk (2009: 112), Keputusan pembelian yaitu pemilihan dari dua atau lebih alternatif pilihan keputusan pembelian, artinya bahwa seseorang bisa membuat keputusan, harus tersedia beberapa alternatif pilihan. Keputusan untuk membeli bisa mengarah pada bagaimana proses dalam pengambilan keputusan tersebut itu dilakukan. Keputusan pembelian konsumen dipengaruhi oleh perilaku konsumen.

Ada enam indicator keputusan pembelian menurut ketler dan keller (2012:479), yaitu :

1. Pemilihan Produk

2. Pemilihan Merek

3. Pemilihan saluran pembelian

4. Penentuan waktu pembelian

5. Jumlah pembelian

6. Metode pembayaran

Dari uraian diatas dapat digambarkan kerangka konseptual sebagai berikut :

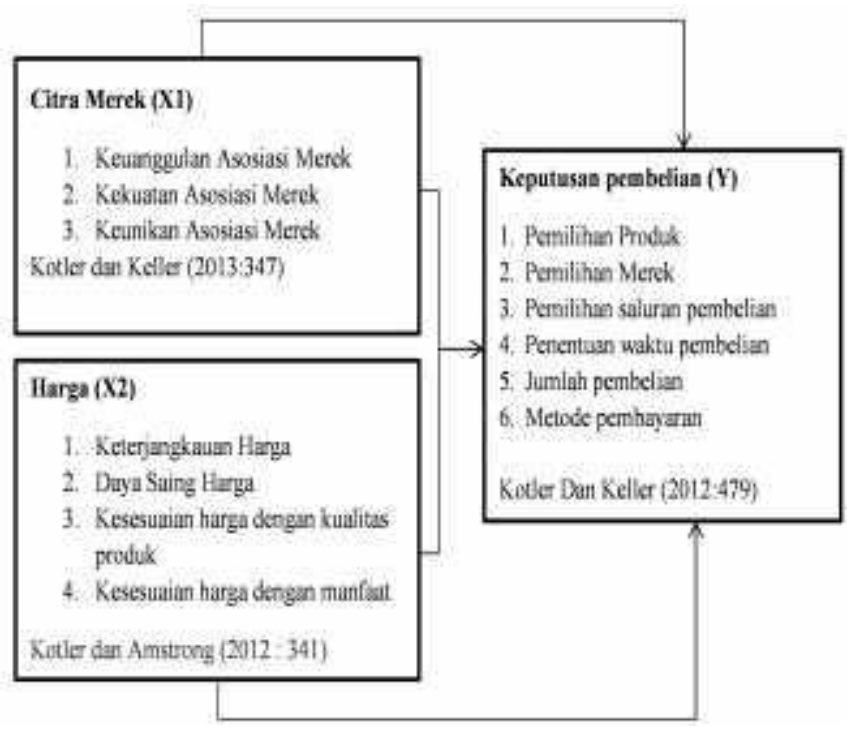




\section{METODE PENELITIAN}

\section{Desain Penelitian}

Desain penelitian merupakan kerangka kondisi pengumpulan data yang bertujuan untuk menjawab tujuan penelitian. Jenis penelitian ini adalah penelitian kuantitatif dengan menggunakan alat SPSS for Windows versi 23.0 untuk mencari gambaran, fenomena, keadaan, peristiwa atau sesuatu yang sedang berlangsung pada saat sekarang berdasarkan fakta-fakta yang terjadi sebagaimana adanya.

Populasi

Sugiyono (2011:61) mengemukakan bahwa populasi adalah wilayah generalisasi yang terdiri atas objek atau subjek, yang mempunyai kualitas dan karakteristik tertentu yang ditetapkan oleh peneliti untuk dipelajari dan kemudian ditarik kesimpulannya. Populasi dalam penelitian ini adalah 1079 mahasiswa Regular fakultas ekonomi dan bisnis Universitas Bandar lampung angkatan 2015-2018.

\section{Sampel}

Penentuan sampel dalam penelitian ini menggunakan Non Probability Sampling, yaitu semua elemen dalam populasi tidak memiliki kesempatan yang sama untuk dipilih menjadi sampel (Ferdinand, 2006:231). Sampel yang digunakan dalam penelitian ini adalah 92 responden.

\section{Uji Validitas}

(Ghozali, 2006). Dengan jumlah sampel (n) adalah 92 tingkat signifikansi 0,1986 . Dimana rumus validitas $\mathrm{df}=\mathrm{n}-2-1$, maka didapat $\mathrm{df}=92-2-1=89$.

Berdasarkan nilai $\alpha 0,05$ dan $\mathrm{df}=89$

diperoleh $r$ tabel sebesar 0,2061

a. $\mathrm{r}$ hitung > r tabel, berarti

pertanyaan tersebut dinyatakan valid. b. $\mathrm{r}$ hitung $<\mathrm{r}$ tabel, berarti pertanyaan tersebut dinyatakan tidak valid.

Dalam melakukan pengujian validitas, digunakan alat ukur berupa program komputer yaitu SPSS for Windows versi 23.0, dan jika suatu alat ukur mempunyai korelasi yang signifikan antara skor item terhadap skor totalnya maka dikatakan alat skor tersebut adalah valid (Ghozali, 2009:71). Adapun hasil uji validitas pada penelitian ini disajikan pada Tabel 3.1.

Tabel 3.3

Uji Validitas

\begin{tabular}{|c|c|c|c|c|}
\hline Variabel & Item & $\mathbf{r}$ hitung & $r$ tabel & Kesimpulan \\
\hline \multirow[t]{6}{*}{ Citra Merek } & $\mathrm{C} 1$ & 0,480 & \multirow[t]{6}{*}{0,206} & Valid \\
\hline & $\mathrm{C} 2$ & 0,607 & & Valid \\
\hline & C3 & 0,227 & & Valid \\
\hline & $\mathrm{C} 4$ & 0,582 & & Valid \\
\hline & $\mathrm{C} 5$ & 0,390 & & Valid \\
\hline & C6 & 0,733 & & Valid \\
\hline \multirow[t]{8}{*}{ Harga } & $\mathrm{H} 1$ & 0,542 & \multirow[t]{8}{*}{0,206} & Valid \\
\hline & $\mathrm{H} 2$ & 0,582 & & Valid \\
\hline & $\mathrm{H} 3$ & 0,360 & & Valid \\
\hline & $\mathrm{H} 4$ & 0,531 & & Valid \\
\hline & $\mathrm{H} 5$ & 0,519 & & Valid \\
\hline & H6 & 0,816 & & Valid \\
\hline & H7 & 0,344 & & Valid \\
\hline & $\mathrm{H} 8$ & 0,379 & & Valid \\
\hline \multirow[t]{12}{*}{ Keputusan Pembelian } & K1 & 0,523 & \multirow[t]{12}{*}{0,206} & Valid \\
\hline & $\mathrm{K} 2$ & 0,435 & & Valid \\
\hline & K3 & 0,510 & & Valid \\
\hline & K4 & 0,636 & & Valid \\
\hline & K5 & 0,716 & & Valid \\
\hline & K6 & 0,712 & & Valid \\
\hline & K7 & 0,466 & & Valid \\
\hline & K8 & 0,712 & & Valid \\
\hline & K9 & 0,721 & & Valid \\
\hline & K10 & 0,584 & & Valid \\
\hline & K11 & 0,602 & & Valid \\
\hline & K12 & 0,588 & & Valid \\
\hline
\end{tabular}

Uji Reliabilitas

Uji reliabilitas digunakan untuk mengukur suatu kuesioner yang merupakan indikator dari variabel. Kuesioner dikatakan reliabel jika jawaban seseorang terhadap kuesioner stabil dari waktu kewaktu.

Dalam melakukan perhitungan Alpha, digunakan alat bantu program komputer yaitu SPSS for Windows versi 23.0 dengan menggunakan model Alpha. Dalam pengambilan keputusan reliabilitas, suatu 
instrumen dikatakan reliabel jika nilai Cronbach Alpha lebih besar dari 0,6 (Ghozali, 2009:72). Hasil uji reabilitas disajikan pada Tabel 3.2.

Tabel 3.4

Uji Reabilitas

\begin{tabular}{|c|c|c|}
\hline Variabel & Alpha Cronbach & Keterangan \\
\hline Citra Merek & 0,766 & Reliabel \\
\hline Harga & 0,796 & Reliabel \\
\hline Keputusan Pembelian & 0,886 & Reliabel \\
\hline
\end{tabular}

Sumber : Data Diolah, 2019

\section{HASIL PENELITIAN DAN PEMBAHASAN \\ Analisis Data Deskriptif}

Instrumen yang digunakan dalam penelitian ini adalah berupa kuesioner, yang terdiri dari 6 butir pernyataan untuk variabel citra merek (X1), 8 butir pernyataan untuk variabel harga (X2), dan 12 butir pernyataan untuk variabel keputusan pembelian (Y), dengan jumlah responden penelitian sebanyak 92 orang mahasiswa Fakultas Ekonomi dan Bisnis Universitas Bandar Lampung. Jawaban responden dibagi menjadi lima kategori (sangat setuju, setuju, ragu-ragu, tidak setuju, dan sangat tidak setuju) dengan interval yang dihitung menggunakan rumus interval. Skor pengelompokkan variabel disajikan pada Tabel 4.1.

Tabel 4.1

Skor Pengelompokkan Variabel

\begin{tabular}{|l|c|c|c|c|c|c|c|c|c|}
\hline \multirow{2}{*}{ Kategori } & \multicolumn{3}{|c|}{ Citra Merek } & \multicolumn{3}{c|}{ Harga } & \multicolumn{3}{c|}{ Keputusan Pembelian } \\
\cline { 2 - 11 } & Interval & Frek & $\%$ & Interval & Frek & $\%$ & Interval & Frek & $\%$ \\
\hline Sangat Setuju & $26-30$ & 5 & 5,43 & $35-40$ & 13 & 14,14 & $52-60$ & 16 & 17,40 \\
\hline Setuju & $21-25$ & 49 & 53,26 & $28-34$ & 55 & 59,78 & $41-50$ & 55 & 59,78 \\
\hline Ragu-ragu & $16-20$ & 36 & 39,14 & $21-27$ & 23 & 25,00 & $32-40$ & 20 & 21,74 \\
\hline Tidak Setuju & $11-15$ & 2 & 2,17 & $14-20$ & 1 & 1,08 & $22-31$ & 1 & 1,08 \\
\hline $\begin{array}{l}\text { Sangat Tidak } \\
\text { Setuju }\end{array}$ & $6-10$ & 0 & 0 & $8-13$ & 0 & 0 & $12-21$ & 0 & 0 \\
\hline Jumlah & & 92 & 100 & & 92 & 100 & & 92 & 100 \\
\hline
\end{tabular}

Sumber : Data diolah, 2019
Berdasarkan data pada Tabel 4.1 diketahui bahwa jawaban responden sebagian besar setuju terhadap ketiga variabel dengan persentase di atas 50\%. Hal ini berarti bahwa sebagian besar responden setuju bahwa citra merek dan Harga menjadi bahan pertimbangan untuk keputusan pembelian sepeda Motor Honda Beat.

Citra Merek merupakan penilaian konsumen tentang apa yang mereka pikirkan dan rasakan terhadap suatu merek. Pada variabel Citra Merek sebesar 53,26\% responden setuju dan $5,43 \%$ responden sangat setuju bahwa Citra Merek dijadikan bahan pertimbangan pembelian sepeda Motor Honda Beat. Sisanya sebesar 39,14\% responden ragu-ragu dan $2,17 \%$ tidak setuju bahwa Citra Merek dijadikan bahan pertimbangan pembelian sepeda Motor Honda Beat.

Harga suatu produk adalah suatu nilai tukar yang disamakan dengan uang untuk manfaat yang diperoleh dari suatu barang dalam kurun waktu tertentu. Pada variabel Harga sebesar 59,78\% responden setuju dan $14,14 \%$ responden sangat setuju bahwa Harga dijadikan bahan pertimbangan pembelian sepeda Motor Honda Beat. Sisanya sebesar $25,00 \%$ responden raguragu dan $1,08 \%$ tidak setuju bahwa Harga dijadikan bahan pertimbangan pembelian sepeda Motor Honda Beat.

Tanggapan responden tentang variabel Keputusan Pembelian dari 92 orang responden responden menyatakan sangat setuju sebanyak 16 orang $(17,40 \%)$, yang menyatakan setuju sebanyak 55 orang $(59,78 \%)$ yang menyatakan ragu-ragu sebanyak 20 orang $(21,74 \%)$ yang menyatakan tidak setuju sebanyak 1 orang $(1,08 \%)$ dan yang menyatakan sangat tidak setuju sebanyak 0 orang $(0 \%)$. 


\section{Model Regresi Linier Berganda}

Analisis ini dilakukan untuk mengetahui seberapa besar ketergantungan variabel terikat (Keputusan Pembelian) dengan variabel bebas (Citra Merek dan Harga). Model regresi linear berganda digunakan untuk mengetahui arah hubungan antara variabel bebas dengan variabel terikat dalam persamaan model regresi linear berganda. Perhitungan model regresi linear berganda dengan menggunakan bantuan program SPSS versi 23 yang disajikan pada Tabel 4.9.

Tabel 4.9

Hasil Pengujian Model Regresi Linear Berganda Secara Parsial

Coefficients

\begin{tabular}{|c|c|c|c|c|c|c|}
\hline \multirow{2}{*}{\multicolumn{2}{|c|}{ Model }} & \multicolumn{2}{|c|}{$\begin{array}{l}\text { Unstandardized } \\
\text { Coefficients }\end{array}$} & \multirow{2}{*}{\begin{tabular}{|l|}
$\begin{array}{l}\text { Standardized } \\
\text { Coefficients }\end{array}$ \\
Beta \\
\end{tabular}} & \multirow[b]{2}{*}{$t$} & \multirow[b]{2}{*}{ Sig. } \\
\hline & & B & Std. Error & & & \\
\hline & (Constant) & 8.018 & 3.434 & & 2.335 & .022 \\
\hline & $\begin{array}{l}\text { Citra } \\
\text { Merek }\end{array}$ & 1.084 & .179 & .524 & 6.060 & .000 \\
\hline & Harga & .459 & .126 & .314 & 3.631 & .000 \\
\hline
\end{tabular}

Sumber : Data diolah, 2019

Dari tabel 4.9 tersebut pada kolom B, tercantum nilai konstanta dan nilai-nila koefisien regresi linier berganda untuk masing-masing variabel bebas. Berdasarkan nilai-nilai tersebut, maka dapat ditentukan nilai regresi linier berganda dinyatakan dalam persamaan sebagai berikut :

Berdasarkan tabel diatas, maka diperoleh persamaan regresi linier berganda sebagai berikut :

$$
\begin{aligned}
& \text { Nilai konstanta (a) }=8,018 \\
& \text { Nilai } b_{1} \quad=1,084 \\
& \text { Nilai } b_{2} \quad=0,459
\end{aligned}
$$

Berdasarkan hasil diatas, kemudian dimasukan ke dalam bentuk regresi linier berganda, sehingga menjadi persamaan sebagai berikut :

$$
\mathrm{Y}=8.018+1.084 \mathrm{X} 1+0.459 \mathrm{X} 2+\mathrm{e}
$$

Keterangan :

$\mathrm{Y} \quad=$ Keputusan Pembelian

$\mathrm{X} 1=$ Citra Merek

$\mathrm{X} 2=$ Harga

\section{Interprestasi :}

Berdasarkan model persamaan di atas , hasil analisis menggunakan bantuan program SPSS dapat dijelaskan sebagai berikut :

a. Nilai konstanta (a) sebesar 8.018 artinya jika tidak memperhatikan citra merek dan harga maka keputusan pembelian sebesar 8,018\%.

b. Untuk nilai koefesien regresi $\mathrm{X}_{1}$ citra merek sebesar 1.084, yang berarti jika harga $\left(\mathrm{X}_{2}\right)$ dianggap konstan maka, jika citra merek ditingkatkan 1 satuan $(1 \%)$ akan meningkatkan keputusan pembelian sebesar 1.084 atau (10.84\%).

c. Untuk nilai koefesien regresi $\mathrm{X}_{2}$ harga sebesar 0,459, yang berarti jika citra merek $\left(\mathrm{X}_{1}\right)$ dianggap tetap maka jika harga ditingkatkan 1 satuan (1\%) akan meningkatkan keputusan pembelian sebesar 0,459 atau $(4,59 \%)$.

Berdasarkan keterangan diatas dapat ditarik kesimpulan bahwa nilai koefesien citra merek $\left(\mathrm{X}_{1}\right)$ lebih kecil dari pada koefesien harga $\left(\mathrm{X}_{2}\right)$. Hal ini menunjukan bahwa kontribusi variabel harga lebih tinggi dibandingkan dengan variabel citra merek dalam meningkatkan keputusan pembelian sepeda motor Honda beat pada mahasiswa FEB Universitas Bandar Lampung

\section{Uji Signifikansi Parameter Individual (Uji statistik t)}

Pengujian hipotesis secara parsial dapat dilakukan untuk mengetahui pengaruh masing-masing variabel bebas terhadap variabel terikat, jika nilai sig $<0,05$ maka 
hipotesis yang diajkan diterima atau Ho ditolak dan Ha diterima.

Tabel 4.10 Uji Hipotesis Secara Parsial (Uji t)

\begin{tabular}{|c|c|c|c|c|c|}
\hline Pengaruh & t hitung & $\begin{array}{r}\text { t tabel }(\mathbf{d f}= \\
\mathbf{8 9 ;} \boldsymbol{\alpha}=\mathbf{0 , 0 5})\end{array}$ & Kondisi & Sig & Kesimpulan \\
\hline $\mathrm{X}_{1}$ ke Y & 6,060 & 1,662 & $\begin{array}{r}\text { thitung }> \\
\mathrm{t} \text { tabel }\end{array}$ & 0,00 & Ho ditolak Ha diterima \\
\hline $\mathrm{X}_{2}$ ke Y & 3,631 & 1,662 & $\begin{array}{r}\text { thitung }> \\
\mathrm{t} \text { tabel }\end{array}$ & 0,00 & Ho ditolak Ha diterima \\
\hline
\end{tabular}

Sumber : Data diolah, 2019

1. Variabel citra merek $\left(\mathrm{X}_{1}\right)$ terhadap keputusan.pembelian (Y) Untuk variabel citra merek diperoleh

nilai $t_{\text {hitung }}$ sebesar 6,060 lebih besar dari nilai $t_{\text {tabel }} 1,662$ atau dengan kata lain $t_{\text {hitung }}>t_{\text {tabel }}$, sedangkan hasil significant yang diperoleh sebesar 0,00 , lebih kecil dari $\alpha$ yang ditentukan yaitu 0,05 sehingga dapat dikatakan significant. Dengan demikian, Ho ditolak dan $\mathrm{Ha}$ diterima, atau dengan kata lain:

Hipotesispertama: citra merek berpengaruh positif dan signifikan terhadap keputusan pembelian sepeda motor Honda beat pada mahasiswa FEB Universitas Bandar Lampung, terbukti dan dapat diterima kebenarannya.

2. Variabel Harga $\left(\mathrm{X}_{2}\right)$ terhadap Keputusan Pembelian (Y)

Untuk variabel Harga diperoleh nilai $t_{\text {hitung sebesar 3,631 lebih besar dari nilai }}$ $t_{\text {tabel }}$ 1,662 atau dengan kata lain $t_{\text {hitung }}>$ $\mathrm{t}_{\text {tabel}}$, sedangkan hasil significant yang diperoleh sebesar 0,000, lebih kecil dari $\alpha$ yang ditentukan yaitu 0,05 sehingga dapat dikatakan significant. Dengan demikian, Ho ditolak dan Ha diterima, atau dengan kata lain:

Hipotesis kedua: Harga berpengaruh positif dan signifikan terhadap keputusan pembelian sepeda motor Honda beat pada mahasiswa FEB Universitas Bandar Lampung, terbukti dan dapat diterima kebenarannya

\section{Uji Signifikansi Kesesuaian Model (Uji Statistik F)}

Analisis dari uji $\mathrm{F}$ ini dimaksudkan untuk menguji hipotesis penelitian yaitu bagaimana pengaruh kualitas pelayanan yang terdiri dari aspek fisik, reability, responsivenes, assurance, serta emptahy dan bagaimana pengaruh citra merek dan harga terhadap keputusan pembelian sepeda motor Honda beat pada mahasiswa FEB Universitas Bandar Lampung. Uji statistik F atau uji signifikansi, pada dasarnya menunjukkan apakah semua variabel bebas yang dimasukkan dalam model mempunyai pengaruh secara bersama-sama terhadap variabel dependen Y. Uji F ini dilakukan dengan membandingkan F-hitung dengan nilai F-tabel pada taraf nyata $\alpha=0,05$. Hasil pengujian dapat dilihat pada tabel berikut ini

Tabel 4.11

Hasil Pengujian Model Regresi Linear Berganda Secara Signifikan ANOVA $^{\mathrm{a}}$

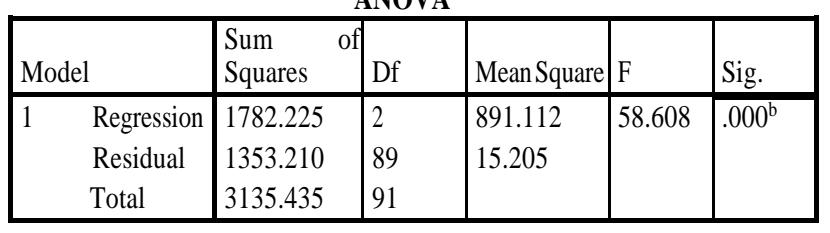

a. Dependent Variable: KeputusanPembelian

b. Predictors: (Constant), Harga, Citra Merek

Sumber : Data diolah, 2019

Berdasarkan tabel diatas, dengan bantuan program SPSS dilihat dari kolom tabel $\mathrm{F}$ diperoleh F-hitung sebesar 58.608. dengan tingkat probabilitas 0.000 (signifikan). Sedangkan F-tabel sebesar 3.95. Berdasarkan hasil analisis penelitian yang telah dilakukan, maka F-hitung lebih besar dari F-tabel (58.608 > 3.95) dan juga probabilitas jauh lebih kecil dari 0.05. Dengan demikian $\mathrm{H}_{0}$ ditolak dan $\mathrm{Ha}$ diterima, yang berarti secara bersama-sama bahwa citra merek $\left(\mathrm{X}_{1}\right)$ dan harga $\left(\mathrm{X}_{2}\right)$ berpengaruh signifikan terhadap keputusan pembelian (Y). 


\section{Koefisien Determinasi $\left(\mathbf{R}^{2}\right)$}

Koefesien determinasi $\left(\mathrm{R}^{2}\right)$ digunakan untuk mengukur seberapa jauh kemampunan model dalam menerangkan variable terikat. Hasil pengujian koefesien determinasi dapat dilihat pada Tabel 4.12.

Tabel 4.12

Hasil Pengujian Model Koefisien Determinasi $\left(\mathbf{R}^{2}\right)$

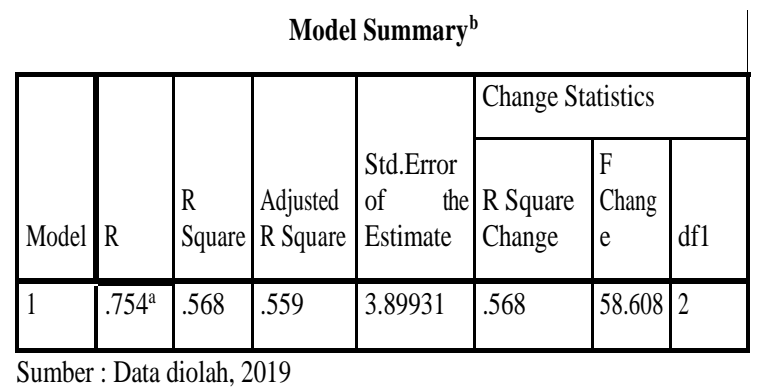

Berdasarkan data pada Tabel

4.12

maka Hasil perhitungan regresi dapat diketahui bahwa koefisien determinasi ( $\mathrm{R}$ Square) yang diperoleh sebesar 0,568. Hal ini berarti $56,8 \%$ Keputusan pembelian sepeda motor Honda beat pada mahasiswa FEB Universitas Bandar Lampung dipengaruhi oleh faktor Citra Merek dan Harga, sedangkan sisanya yaitu 43,2\% dipengaruhi oleh variabel-variabel lainnya yang tidak diteliti dalam penelitian ini.

\section{Kesimpulan}

1. Berdasarkan hasil analisis kuantitatif variable citra merek, harga, dan keputusan pembelian sepeda motor Honda beat pada Mahasiswa Fakultas Ekonomi dan Bisnis Universitas Bandar Lampung berada pada skor setuju.

2. Berdasarkan hasil analisis kuantitatif dengan menggunakan rumus regresi linier berganda dengan rumus $\mathrm{Y}=$ $8,018+1,084 \mathrm{X} 1+0,459 \mathrm{X} 2$, maka dapat disimpulkan dari kedua variabel tersebut menunjukan bahwa terjadi keputusan pembelian yang lebih dominan dipengaruhi oleh citra merek daripada harga.

3. Berdasarkan penelitian terdahulu variabel citra merek (X1) dan harga (X2) secara bersama-sama berpengaruh positif dan signifikan terhadap keputusan pembelian (Y). maka akan semakin mempengaruhi konsumen untuk membeli produk tersebut.

\section{Saran}

1. Perusahaan perlu meningkatkan kualitas dan varian produk sehingga konsumen semakin tertarik untuk membeli sepeda motor Honda Beat.

2. Pihak distributor dan perusahaan perlu meningkatkan kegiatan promosi sehingga sepeda motor Honda Beat lebih dikenal dan memiliki reputasi yang baik di masyarakat.

\section{Daftar Pustaka}

Ferdinan . 2006. Penentuam sampel. Semarang : Badan penerbit Universitas dipenegoro

Ghozali. 2006. Uji Validitas. Semarang : Badan Penerbit Universitas diponegoro.

Ghozali. 2009. Uji Validitas. Semarang : Badan Penerbit Universitas diponegoro.

Kotler. 2008. Pengertian Merek. Edisi 13 jilid 1. Jakarta : Rumah Baca

Kotler. 2013. Indikator Citra Merek. Edisi 13 Jilid 1. Jakarta : Rumah Baca.

Kotler, Amstrong. 2001. Definisi Harga. Jilid 1 dan 2. Jakarta : Erlangga 
Kotler, Amstrong. 2008. Pengertian Merek. Jilid 1 dan 2. Jakarta : Erlangga

Kotler. Amstrong. 20014. Pengertian Citra Merek. Jilid 1 dan 2. Jakarta : Erlangga

Kotler Dan Keller. 20012. Indikator Keputusan Pembelian. Edisi kedua belas. PT Indeks. Kelompok Gramedia. Jakarta.

Lamb. 2008. Pengertian Keputusan Pembelian. PT. Salemba Emban Raya. Jakarta.

Schiffman, Kanuk. 2009. Pengertian Keputusan Pembelian. Edisi 12 jilid 1. Jakarta : Erlangga.
Setiadi. 2003. Pengertian Brand Image. Kencana. Jakarta

Sugiyono. 2011. Pengertian Populasi. Bandung : Alfabet

Sugiyono. 2013. Pengertian Sampel. Bandung : Alfabet

Supranto, J. 2001. Statistik Teori dan Aplikasi. Jilid. Erlangga. Jakarta

http://repository.unpas.ac.id/12795/4/BAB\%20I I.pdf

www.Topbrand-award.com

www.astra-honda.com/price-list\#matic

www.otomotifo.com/harga-yamaha-mio-2018/ 